\title{
Original Paper \\ An efficient method for total RNA extraction from leaves of arboreal species from the Brazilian Cerrado
}

\author{
Geisiane Alves Rocha ${ }^{1,2,3}$, Vanessa Duarte Dias ${ }^{1}$, Renato Carrer-Filho ${ }^{1}$, Marcos Gomes da Cunha ${ }^{1}$ \\ \& Érico de Campos Dianese ${ }^{1}$
}

\begin{abstract}
Considering the lack of information on RNA extraction from arboreal species, specially from the Brazilian Cerrado, the aim of this study was to test RNA extraction methods for a wide variety of native plant species from this biome. The methods tested consisted of: (i) TRIzol ${ }^{\circledR}$ reagent, (ii) TRIzol ${ }^{\circledR}$ reagent with modifications, (iii) CTAB buffer, and (iv) Modified CTAB buffer, initially for leaf samples of Xylopia aromatica and Piper arboreum. Later the procedure with the best results was used to obtain purified RNA from 17 other native species. Based on A260/A280 absorbance ratio the Modified CTAB method was the best for total RNA extraction for those woody species. Ten out of eleven species tested through RT-PCR generated fragments of the expected size from the total RNA extracted by the selected method, confirming it as the best option to obtain high-quality RNA for molecular analyses and for use in the detection of viruses infecting these tree species. Key words: Cerrado Biome, cDNA, RT-PCR, woody species.

Resumo

Considerando a falta de informação para extração de RNA de plantas arbóreas, especialmente as do Cerrado brasileiro, o objetivo do estudo foi testar métodos de extração de RNA para uma ampla variedade de espécies de plantas nativas deste bioma. Os métodos testados foram: (i) reagente TRIzol ${ }^{\circledR}$, (ii) reagente TRIzol ${ }^{\circ} \operatorname{com}$ modificações, (iii) tampão CTAB e (iv) tampão CTAB modificado, inicialmente para amostras foliares de Xylopia aromatica e Piper arboreum. O procedimento com melhores resultados foi utilizado posteriormente para obtenção de RNA de 17 outras espécies nativas. Baseado na razão de absorbância A260/A280 o método com CTAB modificado mostrou-se melhor para extração de RNA destas espécies arbóreas. Dez das onze espécies testadas por meio de RT-PCR geraram fragmentos de tamanho esperado a partir do RNA total extraído utilizando o método selecionado, confirmando-o como melhor opção para obtenção de RNA de alta qualidade para análises moleculares e para uso na detecção de vírus infectando essas espécies arbóreas. Palavras-chave: Bioma Cerrado, cDNA, RT-PCR, espécies lenhosas.
\end{abstract}

\section{Introduction}

Isolation of good quality RNA or DNA is the first step in studies related to plant molecular biology. The methods used in this process were established using the herbaceous Arabidopsis species as model plant, showing chemical and biological properties far different from Neotropical woody plants (Sánchez et al. 2016). Transcriptome studies of tree species help understand numerous plant processes under different conditions, such as gene expression associated with desirable agronomic characteristics (Deng et al. 2016; Ouyang et al. 2016; Shiraishi et al. 2016) related or not to physiological processes such as flowering (Liu et al. 2016) and wood generation (Wang et al. 2016). These studies are dependent on obtaining relatively large amount of high-quality RNA. Thus, efficient protocols for total RNA extraction

\footnotetext{
${ }^{1}$ Universidade Federal de Goiás, Núcleo de Pesquisa em Fitopatologia, Escola de Agronomia, Rod. GO-462, km 0, Campus Samambaia, 74690-900, Goiânia, GO, Brasil.

${ }^{2}$ ORCID: <https://orcid.org/0000-0001-8167-0652>

${ }^{3}$ Author for correspondence: geisiane.agro@gmail.com
} 
from trees are important for genomic analysis of these species, and also for the purpose of detecting infection by plant viruses.

Just a few total RNA extraction methods have proven to be efficient in tree species, such as Quercus robur L. (Kiefer et al. 2000), Hevea brasiliensis (Willd. ex A.Juss.) Müll.Arg. (Deng et al. 2012) and Neolamarckia cadamba (Roxb.) Bosser (Ouyang et al. 2014). In many cases, the efficiency of these methods was not confirmed for trees from the Neotropical savanna (the Cerrado). Most species in this biome are rich in phenolic compounds and polysaccharides that negatively interfere with the quantity and quality of extracted RNA (Cordeiro et al. 2010). As a result, there is some difficulty in studying these plants at the molecular level, despite the fact that some species show desirable characteristics in different areas, including medical interest, production of antimicrobial compounds (Calixto-Júnior et al. 2016; Correia et al. 2016), and allelopathic potential in weed control (Candido et al. 2016).

Given the importance of obtaining substantial amounts of high quality RNA from our native Cerrado trees, especially the non-cultivated species, the aim of this study was to establish the most efficient method for such extractions, since the difficulty in extracting quality RNA from these plants needs a solution to advance the knowledge of the cellular mechanisms present in this unexplored flora.

\section{Material and Methods}

To verify which method would be applied for total RNA extraction from leaf samples of Cerrado arboreal plants, four methods were initially tested for two different species. Of these four methods, the one that showed the best results was chosen for testing in another 17 species of plants native to the Cerrado.

\section{Plant material}

Mature leaves recently collected from three different plants of each species were used. Four different protocols for total RNA extraction were first tested in Xylopia aromatica (Lam.) Mart. and Piper arboreum Aubl. leaves, with three repetitions for each method. For all methods, approximately $100 \mathrm{mg}$ of leaf tissue was ground in $1.5 \mathrm{~mL}$ or 2.0 $\mathrm{mL}$ microtubes using a pestle and liquid nitrogen. Specific amounts of extraction buffer, depending on the method, were added before the samples were thawed to avoid RNA degradation.
The solutions used in all methods were prepared in RNAase-free water:

Method 1 - TRIzol@: $1 \mathrm{~mL}$ of TRIzol reagent (Invitrogen ${ }^{\circledR}$ ) was added to each ground sample. The tube was vortexed for one minute, and then incubated at room temperature for 5 minutes. 200 $\mu \mathrm{L}$ of chloroform were added to each sample and vortexed for 2 minutes, followed by centrifugation at $15,294 \mathrm{rcf}$ for 15 minutes at $4{ }^{\circ} \mathrm{C} .600 \mu \mathrm{L}$ of the supernatant were transferred to new tubes and $420 \mu \mathrm{L}$ of isopropanol was added. The sample was incubated on ice for 5 minutes, followed by centrifugation at 15,294 rcf for 10 minutes. The supernatant was discarded, followed by washing with $600 \mu \mathrm{L}$ of $70 \%$ ethanol (cold) and centrifugation at 15,294 $\mathrm{rcf}$ for 5 minutes at $4{ }^{\circ} \mathrm{C}$. The ethanol was discarded and the tube was kept at room temperature for 2 hours or until the pellets were completely dry. Each sample was resuspended in $30 \mu \mathrm{L}$ of autoclaved Milli-Q water and stored at $-80^{\circ} \mathrm{C}$.

Method 2 - modified TRIzol ${ }^{\circledR}$ (Xiao et al. 2015): $1 \mathrm{~mL}$ of TRIzol ${ }^{\circledR}$ reagent (Invitrogen) was added to ground samples, vortexed vigorously for approximately 30 seconds and incubated at room temperature for 5 minutes. $200 \mu \mathrm{L}$ of chloroform were added to each sample and vortexed once again. The sample was incubated at room temperature for 3 minutes, followed by centrifugation at 17,949 rcf for 3 minutes. Approximately $500 \mu \mathrm{L}$ of the supernatant was transferred to new tubes and 500 $\mu \mathrm{L}$ of isopropanol was added. The sample was maintained at room temperature for 10 minutes and centrifuged at 17,949 $\mathrm{rcf}$ for 10 minutes at 4 ${ }^{\circ} \mathrm{C}$ for pellet formation, followed by disposal of the supernatant. The pellet was washed with $1 \mathrm{~mL}$ of $70 \%$ ethanol (cold). The tube was briefly vortexed, followed by centrifugation at 10,621 ref for 5 minutes at $4{ }^{\circ} \mathrm{C}$. The supernatant was discarded and the tube was kept at room temperature until the pellets were completely dry. Finally, the pellets were resuspended with $30 \mu \mathrm{L}$ of autoclaved Milli-Q water, incubated at $55^{\circ} \mathrm{C}$ for 10 minutes and stored at $-80^{\circ} \mathrm{C}$.

Method 3 - CTAB (Cordeiro et al. 2010): The extraction buffer (2\% CTAB; $2 \%$ PVP; $100 \mathrm{mM}$ Tris/HCl, $\mathrm{pH} 8.0 ; 25$ mM EDTA; $2 \mathrm{M} \mathrm{NaCl}$ ) was pre-heated at $60{ }^{\circ} \mathrm{C}$ and $2 \%$ Beta-mercaptoethanol was added immediately before use. $600 \mu \mathrm{L}$ of this buffer were added to each ground sample. The tube was briefly vortexed and incubated for 15 minutes at $60{ }^{\circ} \mathrm{C} .600 \mu \mathrm{L}$ of chloroform:isoamyl alcohol (24:1) were added. The tube was vortexed 
for 5 minutes followed by centrifugation at 7,700 rcf for 10 minutes. Approximately $450 \mu \mathrm{L}$ of the supernatant was transferred to a new tube and $600 \mu \mathrm{L}$ of chloroform:isoamyl alcohol (24:1) was added. The tube was centrifuged at 7,700 rcf for 10 minutes and $350 \mu \mathrm{L}$ of the supernatant was transferred to a new tube and added with a 7.5 $\mathrm{M}$ lithium chloride solution to the equivalent of $1 / 3$ of the volume of the tube. The sample was maintained for overnight precipitation at 4 ${ }^{\circ} \mathrm{C}$. After precipitation, the tube was centrifuged at 7,700 ref for 30 minutes. The supernatant was discarded and $900 \mu \mathrm{L}$ of Milli-Q water, 0.2 volumes of $2 \mathrm{M}$ sodium acetate $(\mathrm{pH}$ 5.2) and 2 volumes of $100 \%$ ethanol were added. The sample was kept at $-20{ }^{\circ} \mathrm{C}$ for 2 hours for additional precipitation, followed by centrifugation at 7,700 rcf for 30 minutes. The supernatant was discarded and the pellet was washed with $300 \mu \mathrm{L}$ of $70 \%$ ethanol (cold) and centrifuged at 7,700 $\mathrm{rcf}$ for 10 minutes. The pellet was dried at room temperature and resuspended with $30 \mu \mathrm{L}$ of autoclaved Milli-Q water.

Method 4 - CTAB (Chang et al. 1993): Three solutions are needed for this method: $\mathrm{CTAB}$ extraction buffer (2\% CTAB; $2 \%$ PVP 30000; $100 \mathrm{mM}$ Tris/HCl; $25 \mathrm{mM}$ EDTA; $2 \mathrm{M} \mathrm{NaCl}$; spermidine $108 \mu \mathrm{L}$ for $200 \mathrm{~mL}$ of buffer; $2 \%$ Beta-mercaptoethanol) autoclaved without Betamercarptoethanol; SSTE $(1.0 \mathrm{mM} \mathrm{NaCl} ; 0.5 \%$ SDS; $100 \mathrm{mM}$ Tris-HCl pH 8.0; 1.0 mM EDTA pH 8.0); Lithium chloride: EDTA (7.5 $\mathrm{M} \mathrm{LiCl}_{2} ; 50$ mM EDTA). Beta-mercaptoethanol was added to the CTAB buffer and heated at $65^{\circ} \mathrm{C}$ immediately before use. $1 \mathrm{~mL}$ of CTAB buffer was added to each ground sample and vortexed vigorously. The tube with the buffer and sample was heated at $65{ }^{\circ} \mathrm{C}$ for 45 minutes and resuspended through agitation every 10 minutes during heating. Then, $700 \mu \mathrm{L}$ of chloroform was added and the tube was agitated vigorously in a vortex for 5 minutes, followed by centrifugation at $10,621 \mathrm{rcf}$ for 10 minutes. Approximately $600 \mu \mathrm{L}$ of the supernatant was transferred to new tubes $(1.5 \mathrm{~mL})$ and $700 \mu \mathrm{L}$ of chloroform was added, agitated vigorously and centrifuged for 10 minutes at 10,621 rcf. $400 \mu \mathrm{L}$ of supernatant were transferred to new tubes and immediately placed on ice. The same volume of supernatant was added with $\mathrm{LiCl}_{2}$ :EDTA solution and mixed, and the sample was maintained overnight at $4{ }^{\circ} \mathrm{C}$. After precipitation, the sample was centrifuged at 10,621 ref for 20 minutes. The supernatant was discarded and the pellet resuspended with $100 \mu \mathrm{L}$ of SSTE and $50 \mu \mathrm{L}$ of chloroform. The tube was vortexed vigorously for 6 minutes, followed by centrifugation at 15,294 ref for 10 minutes. Approximately $120 \mu \mathrm{L}$ of supernatant was transferred to new tubes and $2 \mathrm{x}$ the volume of $95 \%$ ethanol was added. The sample was kept at $-80{ }^{\circ} \mathrm{C}$ for 20 minutes for the purpose of precipitation. The supernatant was discarded and the pellet washed with $200 \mu \mathrm{L}$ of $70 \%$ ethanol (cold) and centrifuged at 10,621 $\mathrm{rcf}$ for 5 minutes. The pellet was dried at room temperature and resuspended with $30 \mu \mathrm{L}$ of autoclaved Milli-Q water.

After comparing the efficiency of the methods tested for the two species mentioned (X. aromatica and P. arboreum), Method 4 was selected and used to obtain purified RNA from 17 other native woody species (Tab. 1), covering fifteen botanical families.

Assessment of quality and quantity of total RNA extracted and RT-PCR: the purity of extracted RNA was analyzed in a NanoDrop Lite spectrophotometer (Thermo Scientific) adjusting yield values in $\eta \mathrm{g} . \mu \mathrm{L}^{-1}$ and the A260/ A280 absorbance ratio. Integrity was determined based on visualization through $1.2 \%$ agarose gel electrophoresis in TBE buffer, in which were applied $5 \mu \mathrm{L}$ of RNA (above $10 \eta \mathrm{g} . \mu \mathrm{L}^{-1}$ ) in Milli-Q water.

The total RNA extracted with the protocol that showed the best results in NanoDrop and electrophoresis was used in RT-PCR assays. For this step, 11 species were selected, based on different values of RNA yield to verify the viability of these samples in RT-PCR analysis. One sample of each species (Aspidosperma discolor A.DC; Cedrela fissilis Vell.; Emmotum nitens (Benth.) Miers; Ixora sp.; Mabea fistulifera Mart.; Matayba elaeagnoides Radlk.; Nectandra lanceolata Nees; Piper arboreum; Styrax camporum Pohl; Xylpopia aromatica; Zanthoxylum rhoifolium Lam.) was used. A forward (5'-AAACGGCTACCACATCCAAG-3') and reverse (5'-CCTTCAATGGATC-CATCGTTA-3') Gm18SrRNA primer pair, which aligns with the $18 \mathrm{~S}$ gene region (Stolf-Moreira et al. 2010), present in most eukaryotic cells, was used in the reactions. For positive control in RT-PCR, total RNA extracted from soybean by method 1 , which is effective for this type of plant, and RNA extracted by method 4 were used, since the primers were designed based on the genome of this cultivated plant species. 
Table 1 - Species used for total RNA extraction using Method 4.

\begin{tabular}{llc}
\hline Family & Species & No. of samples \\
\hline Annonaceae & Cardiopetalum calophyllum Schltdl. & 3 \\
Apocynaceae & Aspidosperma discolor A.DC. & 3 \\
Araliaceae & Schefflera morototoni (Aubl.) Maguire et al. & 3 \\
Burseraceae & Protium heptaphyllum (Aubl.) Marchand & 1 \\
Chrysobalanaceae & Hirtella glandulosa Spreng. & 3 \\
Chrysobalanaceae & Hirtella gracilipes (Hook.f.) Prance & 2 \\
Euphorbiaceae & Mabea fistulifera Mart. & 3 \\
Lauraceae & Nectandra lanceolata Nees & 3 \\
Melastomataceae & Miconia chamissois Naudin & 1 \\
Meliaceae & Cedrela fissilis Vell. & 3 \\
Meliaceae & Trichilia pallida Sw. & 3 \\
Metteniusaceae & Emmotum nitens (Benth.) Miers & 1 \\
Myristicaceae & Virola sebifera Aubl. & 3 \\
Rubiaceae & Ixora sp. & 3 \\
Rutaceae & Zanthoxylum rhoifolium Lam. & 3 \\
Sapindaceae & Matayba elaeagnoides Radlk. & 3 \\
Styracaceae & Styrax camporum Pohl & 3 \\
\hline
\end{tabular}

Prior to cDNA (complementary DNA) synthesis, the obtained RNA was DNAse treated, according to the manufacturer specifications (Promega $\left.{ }^{\circledR}\right)$. The method (cDNA synthesis) was performed using M-MLV reverse transcriptase (Invitrogen ${ }^{\circledR}$ ). The reaction (for a final volume of $19.5 \mu \mathrm{L}$ ) was prepared with $6.5 \mu \mathrm{L}$ of Milli-Q water, $1 \mu \mathrm{L}$ of dNTPs $(10 \mathrm{mM}), 1 \mu \mathrm{L}$ of reverse primer, $100-200 \mathrm{ng}$ of RNA, $4 \mu \mathrm{L}$ of $5 \mathrm{X}$ RT buffer, $2 \mu \mathrm{L}$ of DTT and $1 \mu \mathrm{L}$ of M-MLV reverse transcriptase. The reaction was kept at $37{ }^{\circ} \mathrm{C}$ for 60 minutes and inactivated through heating at 70 ${ }^{\circ} \mathrm{C}$ for 15 minutes. After cDNA synthesis, PCR was performed with $6.5 \mu \mathrm{L}$ of Milli-Q water, $1 \mu \mathrm{L}$ of $5 \mathrm{X}$ Buffer, $0.3 \mu \mathrm{L}$ of $\mathrm{MgCl}_{2}, 0.7 \mu \mathrm{L}$ of dNTPs $(10 \mathrm{mM}), 0.2 \mu \mathrm{L}$ of each primer (forward and reverse) and $1 \mu \mathrm{L}$ of Taq DNA polymerase (Invitrogen ${ }^{\circledR}$ ). The PCR was carried under the following conditions: initial denaturation at $94^{\circ}$ for one minute, followed by 35 cycles at $95{ }^{\circ} \mathrm{C}$ for two minutes, $62{ }^{\circ} \mathrm{C}$ for 30 seconds, $72{ }^{\circ} \mathrm{C}$ for 30 seconds and, after 35 cycles, a final extension step at $72{ }^{\circ} \mathrm{C}$ for 6 minutes. The PCR products were analyzed by electrophoresis in $1 \%$ agarose gel in TBE $1 \mathrm{X}$ buffer.

\section{Results}

The TRIzol ${ }^{\circledR}$ reagent was ineffective to extract RNA from $P$. arboreum and $X$. aromatica plants, through agarose gel electrophoresis analysis, showing no bands linked to $18 \mathrm{~S}$ and $28 \mathrm{~S}$ rRNAs. Spectrophotometrical analysis showed below optimal A260/A280 ratios for these samples, ranging out of the ideal rates between 1.8 and 2.0 (Fig. S1, available on supplementary material $<$ https://doi.org/10.6084/m9.figshare.12743429. v1>; Tab. 2) (Glasel 1995).

The concentration of RNA extracted with all protocols showed values that varied among the samples. Considering the A260/A280 absorbance values for $P$. arboreum, the values of Methods 1 and 2 were often below 1.5, which is below recommended for RNA quality (Glasel 1995). While for $X$. aromatica, the values showed higher fluctuations, below 1.5 or above 2.5 (Tab. 2). These results were confirmed by agarose gel analysis, in which bands were not visualized (Fig. S1, available on supplementary material $<$ https://doi. org/10.6084/m9.figshare.12743429.v1>; Tab. 2).

For Methods 3 and 4, the A260/A280 ratios for both species resulted in better values (Tab. 2; 
Table 2 - Productivity values and absorbance ratio of total RNA extraction from leaf samples of Piper arboreum and Xylopia aromatica using four different methods.

\begin{tabular}{|c|c|c|c|c|c|c|c|c|c|}
\hline \multicolumn{10}{|c|}{ Piper arboreum } \\
\hline \multirow[b]{2}{*}{ Extraction } & \multirow[b]{2}{*}{ Sample* } & \multicolumn{2}{|c|}{ Method 1} & \multicolumn{2}{|c|}{ Method 2} & \multicolumn{2}{|c|}{ Method 3} & \multicolumn{2}{|c|}{ Method 4} \\
\hline & & Yield & $\begin{array}{c}\text { Absorbance } \\
\text { ratio } \\
\text { A260/A280 }\end{array}$ & Yield & $\begin{array}{c}\text { Absorbance } \\
\text { ratio } \\
\text { A260/A280 }\end{array}$ & Yield & $\begin{array}{c}\text { Absorbance } \\
\text { ratio } \\
\text { A260/A280 }\end{array}$ & Yield & $\begin{array}{c}\text { Absorbance } \\
\text { ratio } \\
\text { A260/A280 }\end{array}$ \\
\hline \multirow{9}{*}{1} & P1a & 24.1 & 1.40 & 98.5 & 1.30 & 43.8 & 1.91 & 37.1 & 2.05 \\
\hline & P1b & 39.8 & 1.43 & 24.0 & 1.44 & 43.8 & 2.04 & 29.9 & 2.09 \\
\hline & $\mathrm{P} 1 \mathrm{c}$ & 27.5 & 1.13 & 53.4 & 1.45 & 53.1 & 1.70 & 53.2 & 2.02 \\
\hline & $\mathrm{P} 2 \mathrm{a}$ & 3.6 & 1.10 & 29.4 & 1.68 & 77.8 & 2.18 & 96.2 & 2.09 \\
\hline & $\mathrm{P} 2 \mathrm{~b}$ & 25.2 & 1.46 & 8.8 & 1.65 & 43.3 & 1.80 & 118.5 & 2.03 \\
\hline & $\mathrm{P} 2 \mathrm{c}$ & 16.4 & 1.17 & 10.3 & 1.09 & 41.7 & 2.01 & 53.2 & 2.02 \\
\hline & P3a & 6.7 & 1.01 & 28.6 & 1.41 & 45.8 & 1.79 & 43.0 & 1.90 \\
\hline & $\mathrm{P} 3 \mathrm{~b}$ & 48.4 & 1.47 & 17.2 & 3.54 & 42.0 & 2.08 & 42.6 & 2.01 \\
\hline & $\mathrm{P} 3 \mathrm{c}$ & 40.4 & 1.29 & 5.9 & 1.22 & 59.0 & 2.23 & 62.1 & 2.02 \\
\hline \multirow{9}{*}{2} & P1a & 17.0 & 1.08 & 43.2 & 0.92 & 43.8 & 2.18 & 32.4 & 2.02 \\
\hline & Plb & 6.4 & 1.15 & 7.4 & 1.20 & 38.5 & 2.18 & 32.8 & 1.99 \\
\hline & P1c & 16.6 & 0.81 & 8.2 & 1.03 & 38.9 & 2.22 & 33.4 & 2.00 \\
\hline & $\mathrm{P} 2 \mathrm{a}$ & 6.0 & 1.12 & 4.4 & 1.09 & 55.3 & 1.97 & 45.1 & 1.94 \\
\hline & $\mathrm{P} 2 \mathrm{~b}$ & 4.9 & 1.22 & 62.2 & 1.11 & 39.0 & 2.04 & 38.1 & 1.88 \\
\hline & $\mathrm{P} 2 \mathrm{c}$ & 7.6 & 0.86 & 4.2 & 1.14 & 45.6 & 1.83 & 11.6 & 2.01 \\
\hline & P3a & 4.1 & 0.99 & 12.2 & 1.09 & 44.5 & 2.09 & 88.9 & 2.01 \\
\hline & P3b & 8.1 & 0.93 & 8.0 & 1.22 & 44.6 & 1.92 & 75.4 & 2.01 \\
\hline & $\mathrm{P} 3 \mathrm{c}$ & 1.0 & 1.13 & 96.8 & 1.44 & 27.0 & 2.08 & 97.3 & 2.08 \\
\hline \multirow{9}{*}{3} & Pla & 19.6 & 1.09 & 79.6 & 1.24 & 17.1 & 1.34 & 62.1 & 2.02 \\
\hline & $\mathrm{P} 1 \mathrm{~b}$ & 19.0 & 1.13 & 44.2 & 1.45 & 2.6 & 1.87 & 72.1 & 2.01 \\
\hline & $\mathrm{P} 1 \mathrm{c}$ & 31.5 & 1.15 & 37.8 & 1.48 & 2.7 & 1.56 & 73.0 & 2.09 \\
\hline & $\mathrm{P} 2 \mathrm{a}$ & 22.4 & 1.19 & 37.1 & 1.51 & 3.4 & 1.65 & 80.2 & 2.00 \\
\hline & $\mathrm{P} 2 \mathrm{~b}$ & 29.5 & 1.23 & 54.1 & 1.30 & 5.6 & 1.67 & 70.0 & 2.02 \\
\hline & $\mathrm{P} 2 \mathrm{c}$ & 6.8 & 1.18 & 49.0 & 0.94 & 6.2 & 1.63 & 79.8 & 2.01 \\
\hline & P3a & 44.5 & 1.23 & 83.2 & 2.24 & 4.2 & 1.60 & 78.8 & 2.08 \\
\hline & $\mathrm{P} 3 \mathrm{~b}$ & 24.5 & 0.95 & 52.7 & 2.30 & 7.0 & 1.54 & 80.7 & 2.15 \\
\hline & $\mathrm{P} 3 \mathrm{c}$ & 37.5 & 1.25 & 54.6 & 2.77 & 3.3 & 1.78 & 111.5 & 2.04 \\
\hline
\end{tabular}




\begin{tabular}{|c|c|c|c|c|c|c|c|c|c|}
\hline \multicolumn{10}{|c|}{ Xylopia aromatica } \\
\hline \multirow[b]{2}{*}{ Extraction } & \multirow[b]{2}{*}{ Sample } & \multicolumn{2}{|c|}{ Method 1} & \multicolumn{2}{|c|}{ Method 2} & \multicolumn{2}{|c|}{ Method 3} & \multicolumn{2}{|c|}{ Method 4} \\
\hline & & Yield & $\begin{array}{c}\text { Absorbance } \\
\text { ratio } \\
\text { A260/A280 }\end{array}$ & Yield & $\begin{array}{c}\text { Absorbance } \\
\text { ratio } \\
\text { A260/A280 }\end{array}$ & Yield & $\begin{array}{c}\text { Absorbance } \\
\text { ratio } \\
\text { A260/A280 }\end{array}$ & Yield & $\begin{array}{c}\text { Absorbance } \\
\text { ratio } \\
\text { A260/A280 }\end{array}$ \\
\hline \multirow{9}{*}{1} & X1a & 102.5 & 1.59 & 86.3 & 1.29 & 2.5 & 1.94 & 44.7 & 2.02 \\
\hline & $\mathrm{X} 1 \mathrm{~b}$ & 141.5 & 1.30 & 36.6 & 1.30 & 3.2 & 1.90 & 42.4 & 2.09 \\
\hline & $\mathrm{X} 1 \mathrm{c}$ & 82.5 & 3.73 & 19.5 & 0.73 & 14.2 & 2.01 & 46.5 & 2.05 \\
\hline & $\mathrm{X} 2 \mathrm{a}$ & 86.4 & 0.94 & 56.3 & 0.99 & 3.1 & 2.03 & 38.5 & 2.05 \\
\hline & $\mathrm{X} 2 \mathrm{~b}$ & 24.0 & 1.82 & 74.6 & 1.02 & 3.1 & 1.90 & 43.3 & 2.12 \\
\hline & $\mathrm{X} 2 \mathrm{c}$ & 18.6 & 1.36 & 91.2 & 1.26 & 3.1 & 1.70 & 39.4 & 2.09 \\
\hline & $\mathrm{X} 3 \mathrm{a}$ & 52.1 & 1.26 & 18.1 & 1.26 & 3.5 & 2.01 & 42.1 & 1.90 \\
\hline & $\mathrm{X} 3 \mathrm{~b}$ & 29.4 & 1.15 & 15.6 & 1.10 & 2.4 & 2.28 & 42.6 & 2.17 \\
\hline & $\mathrm{X} 3 \mathrm{c}$ & 38.5 & 1.53 & 44.9 & 1.56 & 3.4 & 1.79 & 43.2 & 2.09 \\
\hline \multirow{9}{*}{2} & $\mathrm{X} 1 \mathrm{a}$ & 22.6 & 1.23 & 57.4 & 1.43 & 6.7 & 2.06 & 42.0 & 2.02 \\
\hline & $\mathrm{X} 1 \mathrm{~b}$ & 60.7 & 0.98 & 33.6 & 1.34 & 3.3 & 2.11 & 34.5 & 2.05 \\
\hline & $\mathrm{X} 1 \mathrm{c}$ & 50.2 & 0.77 & 14.1 & 1.05 & 8.4 & 2.27 & 26.3 & 1.97 \\
\hline & $\mathrm{X} 2 \mathrm{a}$ & 32.1 & 1.22 & 98.8 & 0.89 & 3.2 & 1.72 & 28.3 & 2.08 \\
\hline & $\mathrm{X} 2 \mathrm{~b}$ & 21.7 & 1.45 & 47.8 & 1.02 & 15.4 & 1.79 & 14.1 & 2.04 \\
\hline & $\mathrm{X} 2 \mathrm{c}$ & 15.2 & 1.32 & 33.0 & 1.23 & 2.7 & 1.49 & 17.8 & 2.09 \\
\hline & X3a & 20.7 & 1.32 & 76.9 & 2.87 & 6.7 & 2.04 & 41.9 & 2.04 \\
\hline & $\mathrm{X} 3 \mathrm{~b}$ & 50.6 & 1.17 & 47.8 & 2.43 & 7.5 & 1.92 & 45.4 & 2.09 \\
\hline & $\mathrm{X} 3 \mathrm{c}$ & 30.3 & 1.08 & 123.9 & 1.40 & 4.6 & 1.91 & 60.3 & 2.08 \\
\hline \multirow{9}{*}{3} & $\mathrm{X} 1 \mathrm{a}$ & 8.4 & 1.29 & 10.8 & 1.01 & 18.6 & 1.95 & 8.9 & 1.95 \\
\hline & $\mathrm{X} 1 \mathrm{~b}$ & 9.9 & 1.03 & 4.0 & 0.99 & 3.7 & 1.53 & 10.7 & 1.93 \\
\hline & $\mathrm{X} 1 \mathrm{c}$ & 58.4 & 1.09 & 12.6 & 0.91 & 9.3 & 2.10 & 9.5 & 1.85 \\
\hline & $\mathrm{X} 2 \mathrm{a}$ & 15.5 & 1.38 & 16.4 & 1.23 & 7.3 & 1.65 & 13.6 & 1.93 \\
\hline & $\mathrm{X} 2 \mathrm{~b}$ & 54.2 & 2.67 & 35.4 & 1.12 & 8.1 & 2.02 & 8.1 & 1.92 \\
\hline & $\mathrm{X} 2 \mathrm{c}$ & 80.2 & 1.43 & 10.8 & 1.15 & 10.7 & 2.05 & 6.7 & 2.05 \\
\hline & X3a & 63.7 & 1.01 & 26.4 & 1.45 & 15.7 & 1.86 & 5.7 & 2.06 \\
\hline & $\mathrm{X} 3 \mathrm{~b}$ & 73.1 & 0.99 & 59.1 & 1.51 & 7.5 & 1.91 & 4.1 & 2.15 \\
\hline & $\mathrm{X} 3 \mathrm{c}$ & 52.3 & 1.21 & 36.1 & 1.33 & 4.3 & 1.99 & 8.3 & 1.95 \\
\hline
\end{tabular}

*P1 to P3 and X1 to X3 refer to samples from three different plants with three replicates each ('a' to 'c'). The extraction using each method was perfomed three times (Extraction 1 to 3 ). 
Fig. 1; Fig. S1, available on supplementary material $<$ https://doi.org/10.6084/m9.figshare.12743429. v1 $>$ ). For $P$. arboreum samples, Method 4 proved to be the most effective since it was possible to visualize bands related to rRNAs (Fig. 1) on three extractions, with A260/A280 values within optimal ranges (Tab. 2). For $X$. aromatica, similar results were obtained in two out of three extractions (Tab. 2), different from Method 3 where the results were obtained only for P. arboreum (Tab. 2; Fig. S1, available on supplementary material $<$ https:/doi. org/10.6084/m9.figshare.12743429.v1>). Method 3 failed to generate visible bands in most samples and was considered inefficient. Thus, Method 4 showed to be more efficient for total RNA extraction for this type of plant and was selected for the tests involving 17 other native species from the Brazilian Cerrado (Tab. 1). When using Method 4, the pellet presented white coloration, slightly transparent, easily resuspended. Differently from Methods 1 and 2 in which the pellet was viscous and yellowish in color, and from Method 3 in which in most samples was not visible.

Spectrophotometer and agarose gel analysis varied among the tested species (Fig. 2; Fig. S2, available on supplementary material $<$ https://doi. org/10.6084/m9.figshare.12743429.v1>), which was expected because they belong to different botanical families. After the RNA extraction by method 4, RT-PCR of 11 out of 17 species was performed. The fragments of $151 \mathrm{bp}$ were amplified for 10 species, with soybean samples used as positive controls (Fig. 3).

\section{Discussion}

The TRIzol $\AA$-based methods 1 and 2 were not able to eliminate all contaminants that may interfere in the reactions leading to the extraction of high quality RNA. Such contaminants, probably phenolic compounds and polysaccharides, are present in high concentration in most woody species from the Brazilian Cerrado, such as $X$. aromatica (Stashenko et al. 2004). These contaminants can be held responsible for the viscous and yellowish appearance of the obtained pellet, which made the resuspension procedure difficult.

Phenolic compounds can irreversibly bind to nucleic acids, co-precipitating with RNA, thereby reducing the quality of the final product (Chang et al. 1993; Peng et al. 2014). In Methods 3 and 4, PVP and Beta-mercaptoethanol reagents are used as reducing agents to avoid oxidation of phenolic

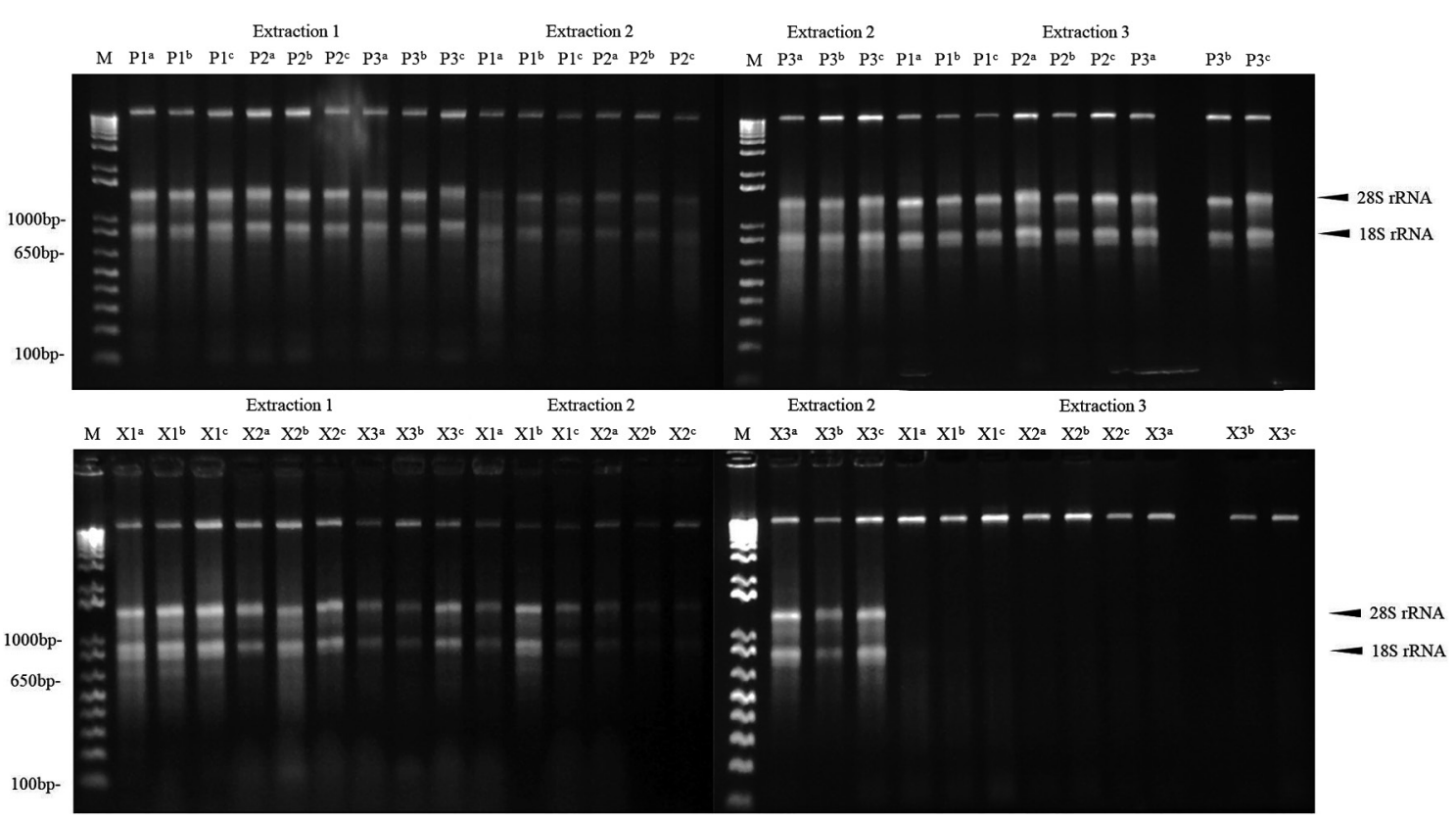

Figure 1 - Extraction of total RNA of Brazilian Cerrado arboreal species. Electrophoresis in 1.2\% agarose gel of total RNA extraction by method 4. $\mathrm{M}=$ Marker $1 \mathrm{~Kb}$ Plus Ladder (Invitrogen ${ }^{\circledR}$ ); $\mathrm{P}=$ Piper arboreum; $\mathrm{X}=$ Xylopia aromatica. a, b and c: sample of different plants. 1, 2 and 3: repetitions for each plant. Extraction 1, 2 and 3: each time the procedure was repeated. 


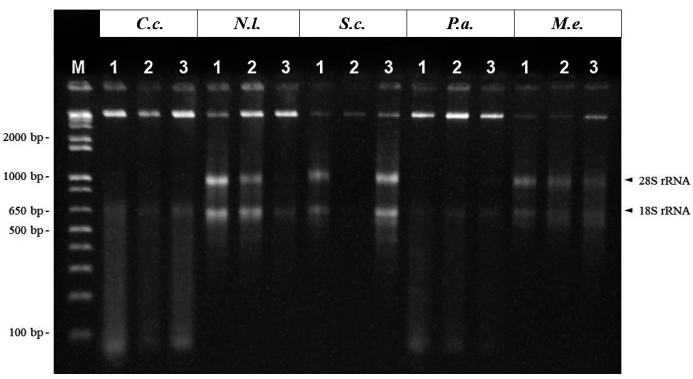

Figure 2-Electrophoresis in 1.2\% agarose gel of total RNA extraction by method 4-CTAB for five arboreal species from the Brazilian Cerrado. $\mathrm{M}=$ Marker 1 Kb Plus Ladder (Invitrogen $\AA$ ); C.c. $=$ Cardiopetalum calophyllum; N.l. = Nectandra lanceolata; S.c. = Styrax camporum; P.a. = Piper arboreum; M.e. $=$ Matayba elaeagnoides. 1, 2 and 3 are different samples of each species.

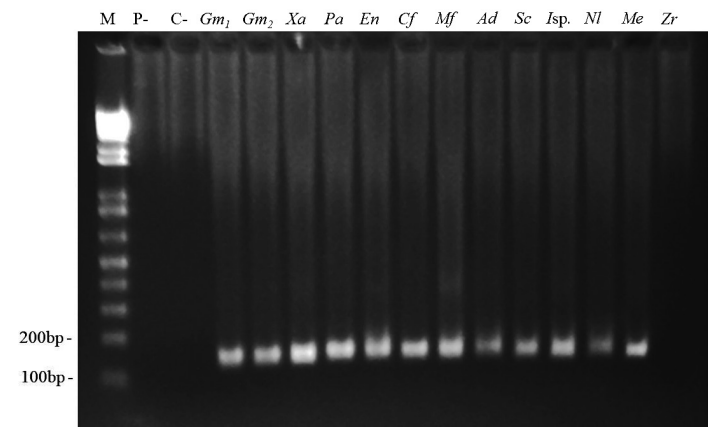

Figure 3 - RT-PCR of total RNA extracted by method 4 from five woody species from the Brazilian Cerrado using the Gm18SrRNA primer pair. $\mathrm{M}=$ Marker $1 \mathrm{~Kb}$

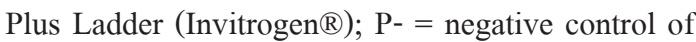
$\mathrm{PCR}$ reaction; $\mathrm{C}-=$ negative control of cDNA synthesis; $G m_{1}=$ Glycine $\max \left(\right.$ extraction by method 1); $G m_{2}=$ Glycine max (extraction by method 4) Xa=Xylopia aromatica; $\mathrm{Pa}=$ Piper arboreum $\mathrm{En}=$ Emmotum nitens; $C f=$ Cedrela fissilis; $M f=$ Mabea fistulifera; $A d$ = Aspidosperma discolor; $S c=$ Styrax camporum; Isp. = Ixora sp.; $N l=$ Nectandra lanceolata $; M e=$ Matayba elaeagnoides; $\mathrm{Zr}=$ Zanthoxylum rhoifolium.

compounds. Furthermore, in Method 4 the high concentrations of $\mathrm{NaCl}$ on CTAB buffer and SSTE might have helped in polysaccharide removal (Chang et al. 1993).

Nevertheless, the main difference in efficiency of Method 4 over Method 3 is in the use of spermidine, a polyamine that is involved in cellular metabolism in different tissues. In plants, spermidine, and other polyamines are correlated with the response to abiotic stress and antioxidant activity (Diao et al. 2017; Liu et al. 2017; Zhang et al. 2017). Thus, spermidine may be directly related to maintenance of RNA quality throughout the extraction process by Method 4.

The quality of the extracted RNA is often revealed by the visualization of clear bands in agarose gel when it comes to the $18 \mathrm{~S}$ and $28 \mathrm{~S}$ regions of ribosomal RNA. The purity of the bands can be measured by the absorbance ratio A260/ A280. This ratio indicates the level of protein contamination, based on the principle that nucleic acids and proteins exhibit optimal absorbance values of $260 \mathrm{~nm}$ and $280 \mathrm{~nm}$ respectively (Glasel 1995; Mathieson \& Thomas 2013). Thus, the best values are between 1.5 and 2.0 in $260 \mathrm{~nm}$, which represents how much nucleic acid is present in the solution in relation to the amount of proteins. The maximum of 2.0 is considered as above that value, the amount of RNA may be so high that it will negatively interfere with RT-PCR (Tattersall \& Ergul 2005).

The TRIzol@ reagent was feasible for herbaceous plants, such as the RNA extracted from soybean samples used in RT-PCR (Fig. 3). When this reagent was used for RNA extraction of woody species, the result was unsatisfactory. This may be explained by the chemical composition of these tree species, with high concentration of phenolic compounds and polysaccharides, interfering negatively in the reactions (Moreira et al. 2003; Calixto-Júnior et al. 2016).

The lack of phenol on the methods that presented the best results contributed to the production of appropriate samples for cDNA synthesis and subsequent quality of the RT-PCR products (Chang et al. 1993). This was shown when RT-PCR amplifications were satisfactory in ten out of 11 native tree species samples used (Fig. 3). The Zanthoxylum rhoifolium sample probably did not amplify through RT-PCR because of its low RNA concentration and high DNA that was eliminated in the DNAse treatment (Fig. S2, available on supplementary material < https://doi.org/10.6084/ m9.figshare.12743429.v1>).

Taking into account the differences in the composition of the Brazilian Cerrado tree species used in this work, it can be concluded that Method 4 showed efficiency for extraction of high-quality RNA from most of the species in this study. Thus, it is possible to recommend Method 4 for wide 
use in molecular studies involving our native tree species, including the diagnosis of viral diseases via RT-PCR.

\section{Acknowledgements}

This research was supported by CAPES (Coordenação de Aperfeiçoamento de Pessoal de Nível Superior) grants. We would like to thank prof. José Carmine Dianese for reviewing the final draft of this paper.

\section{References}

Calixto-Júnior JT, Morais SM, Gomez CV, Molas CC, Rolon M, Boligon AA, Athayde ML, Oliveira CDM, Tintino SR \& Coutinho HDM (2016) Phenolic composition and antiparasitic activity of plants from the Brazilian Northeast "Cerrado". Saudi Journal of Biological Sciences 23: 434-440.

Candido LP, Varela RM, Torres A, Molinillo JMG, Gualtieri SCJ \& Macías FA (2016) Evaluation of the allelopathic potential of leaf, stem, and root extracts of Ocotea pulchella Nees et Mart. Chemistry \& Biodiversity 13: 1058-1067.

Chang S, Puryear J \& Cairney J (1993) A simple and efficient method for isolating RNA from pine trees. Plant Molecular Biology Reporter 11: 113-116.

Cordeiro MCR, Fragoso RR, Silva MS \& Barros LMG (2010) Protocolo para extração de RNA de plantas nativas do Bioma Cerrado e Amazônico. Comunicado Técnico 170 -Embrapa Cerrados: 1-4.

Correia AF, Silveira D, Fonseca-Bazzo YM, Magalhães PO, Fagg CW, Silva EC, Gomes SM, Gandolfi RP, Pratesi R \& Nóbrega YKM (2016) Activity of crude extracts from Brazilian cerrado plants against clinically relevant Candida species. BMC Complementary and Alternative Medicine 16: 1-9.

Deng LH, Luo MW, Zhang CF \& Zeng HC (2012) Extraction of high-quality RNA from rubber tree leaves. Bioscience, Biotechonology, and Biochemistry 76: 1394-1396.

Deng LT, Wu YL, Li JC, Ouyang KX, Ding MM, Zhang JJ, Li SQ, Lin MF, Chen HB, Hu XS \& Chen XY (2016) Screening reliable reference genes for RTq-PCR analysis of gene expression in Moringa oleifera. Plos One 11: e0159458. DOI:10.1371/ journal.pone.0159458

Diao Q, Song Y, Shi D \& Qi H (2017) Interaction of polyamines, abscisic acid, nitric oxide, and hydrogen peroxide under chilling stress in tomato (Lycopersicon esculentum Mill.) seedlings. Frontiers in Plant Science 8: 203. DOI: 10.3389/ fpls.2017.00203.

Glasel JA (1995) Validity of nucleic acid purities monitored by $260 \mathrm{~nm} / 280 \mathrm{~nm}$ absorbance ratios. Biotechniques 18: 62-63.
Kiefer E, Heller W \& Ernst D (2000) A simple and efficient protocol for isolation of functional RNA from plant tissues rich in secondary metabolites. Plant Molecular Biology Reporter 18: 33-39.

Liu H, Fu J, Du H, Hu J \& Wuyun T (2016) De novo sequencing of Eucommia ulmoides flower bud transcriptomes for identification of genes related to floral development. Genomics Data 9: 105-110. DOI: 10.1016/j.gdata.2016.07.001.

Liu M, Chen J, Guo Z \& Lu S (2017) Differential responses of polyamines and antioxidants to drought in a centipedegrass mutant in comparison to its wild type plants. Frontiers in Plant Science 8: 792. DOI: 10.3389/fpls.2017.00792.

Mathieson W \& Thomas GA (2013) Simultaneously extracting DNA, RNA, and protein using kits: is sample quantity or quality prejudiced? Analytical Biochemistry 433: 10-18.

Moreira IC, Lago JHG \& Roque N (2003) Alkaloid, flavonoids, and terpenoids from leaves and fruits of Xylopia aromatica (Annonaceae). Biochemical Systematics and Ecology 31: 535-537. DOI: 10.1016/S0305-1978(02)00180-1.

Ouyang K, Li J, Huang H, Que Q, Li P \& Chen X (2014) A simple method for RNA isolation from various tissues of the tree Neolamarckia cadamba. Biotechnology \& Biotechnological Equipment 28: 1008-1013.

Ouyang K, Li J, Zhao X, Zhao X, Que Q, Li P, Huang H, Deng X, Singh SK, Wu AM \& Chen X (2016) Transcriptomic analysis of multipurpose timber yielding tree Neolamarckia cadamba during xylogenesis using RNA-seq. Plos One 11: e0159407. DOI:10.1371/journal.pone.0159407.

Peng J, Xia Z, Chen L, Shi M, Pu J, Guo J \& Fan Z (2014) Rapid and efficient isolation of high-quality small RNAs from recalcitrant plant species rich in polyphenols and polysaccharides. Plos One 9: e95687. DOI:10.1371/journal.pone.0095687.

Sánchez C, Villacreses, J, Blanc N, Espinoza L, Martinez C, Pastor G, Manque P, Undurraga SF \& Polanco V (2016) High quality RNA extraction from Maqui berry for its application in next-generation sequencing. SpringerPlus 5: 1243. DOI: $10.1186 /$ s40064-016-2906-x.

Shiraishi A, Murata J, Matsumoto E, Matsubara S, Ono E \& Satake H (2016) De Novo Transcriptomes of Forsythia koreana using a novel assembly method: Insight into tissue- and species-specific expression of lignan biosynthesis-related gene. Plos One 11: e0164805. DOI:10.1371/journal.pone.0164805.

Stashenko EE, Jaramillo BE \& Martínez JR (2004) Analysis of volatile secondary metabolites from Colombian Xylopia aromatica (Lamarck) by different extraction and headspace methods gas chromatography. Journal of Chromatography A 1025: 105-113. DOI: 10.1016/j.chroma.2003.10.05. 
Stolf-Moreira R, Medri ME, Neumaier N, Lemos NG, Pimenta JA, Tobita S, Brogin RL, MarcelinoGuimarães FC, Oliveira MCN, Farias JRB, Abdelnoor RV \& Nepomuceno AL (2010) Soybean physiology and gene expression during drought. Genetics and Molecular Research 9: 1946-1956.

Tattersall EAR \& Ergul A (2005) Comparison of methods for isolating high-quality RNA from leaves of grapevine. American Journal of Enology and Viticulture 56: 400-407.

Wang Q, Ci D, Li T, Li P, Song YP, Chen J, Quan M, Zhou D \& Zhang D (2016) The role of DNA methylation in xylogenesis in different tissues of poplar. Frontiers in Plant Science 7: 1003. DOI: 10.3389/fpls.2016.01003.

Xiao H, Kim WS \& Meng B (2015) A highly effective and versatile technology for the isolation of RNAs from grapevines and other woody perennials for use in virus diagnostics. Virology Journal 12: 171. DOI: 10.1186/s12985-015-0376-3.

Zhang L, Hu T, Amombo E, Wang G, Xie Y \& Fu J (2017) The alleviation of heat damage to photosystem II and enzymatic antioxidants by exogenous spermidine in tall fescue. Frontiers in Plant Science 8: 1747. DOI: $10.3389 /$ fpls.2017.01747. 